\title{
The Issue of Marketing Innovation in Financial Services: Case of the Banks and Insurance
}

\author{
Mohamed Cherchem ${ }^{1}$ \\ ${ }^{1}$ Faculty of Management and Economics, University of Oran, Oran, Algeria \\ Correspondence: Mohamed Cherchem, Faculty of Management and Economics, University of Oran, Oran, \\ Algeria. Tel: 213-553-264-863. E-mail: mcherchem@yahoo.fr
}

Received: June 19, 2012 Accepted: September 3, 2012 Online Published: October 24, 2012

doi:10.5539/ijbm.v7n22p109 URL: http://dx.doi.org/10.5539/ijbm.v7n22p109

\begin{abstract}
Innovation is at the center of much debate on the competitiveness of business services including financial institutions and profitability of banks. This paper focuses on innovation in marketing services including in the Algerian public banks. In this paper, we show that the relative importance dimensions of innovation in services correlated with those of the marketing culture that is be omnipresent in the bank.

An empirical study allows us to evaluate and estimate the innovation in services including In the Algerian public banks, through a field study (interview guide) with officials of public sector banks Algeria, as well as private customers.
\end{abstract}

Keywords: innovation, services, marketing banking

\section{Introduction}

Majority of their contribution to employment and value-added services are at the heart of contemporary economies, they represent nearly $70 \%$ of gross domestic product They Represent Nearly $70 \%$ of gross domestic product and the use of all developed countries (OECD 2006).

The tertiary employment is now large majority of countries industrialized; nearly three quarters in the United States, 7/10 France and the United Kingdom, more than 6/10 in Germany and Japan are in Services (OECD, 2006).

Through this vision, the services were perceived until recently little as innovative: The overall conclusion is that they were little R\&D and merely embedding produced upstream in the manufacturing sector (Frascati Manual) Although recognized today as the engine of economic growth and job creation in all countries industrialized services have been recently investigated which helped break with the image of refractory services to innovation clearly demonstrating that innovative services but often in other forms in the manufacturing (Oslo Manual and CIS3).

There has been a stream of product innovation and banking services that are scalable increasingly new preferences and expectations customers; the bank marketing is also called, more than ever, to play a role and determinant in this area. The ability innovation gives the bank the extent of its survival and vigor. It involves energy, imagination, and creativity, sense of market, its opportunities and its future. But this could be done by a process strategic and operational marketing effective and innovation strategy.

This paper presents a framework for innovation financial services from sources theoretical faces an empirical case to lead to a generalization based on our observations. The study was conducted in two parts: the first part deals with the concepts of innovation in general and Services particular and the process of creation and strategic and organizational implications new banking products and services, we also discussed the policy implications and operational banking innovation and instead who serves as R\&D structures. And we conclude with the prerequisites for success banking innovation.

The second part is empirical and allows us evaluate and assess innovation in services particularly in the Algerian public banks that activate in the Algerian market, through a field study (interview guide)with officials of public sector banks Algerian as well as from the customer individuals.

This reflection will lead us to the Algerian context we observe in recent years. The development means 
information and communication, the nature of increasingly open the Algerian economy, awareness and demand more or less enlightened consumer Algerian, all these are factors that constantly upset or rather revolutionize the traditional labor institutions Algerian financial.

\section{Literature Review}

Several studies have analyzed and success factors and causes of failures innovations: A.D. Little (1997) Cooper (1979, 1982,1993), les études de la PDMA (1993), Edgett, Shplay et Forbes (1992), L'IPEE (1990), Booz, Allen et Hamilton (1982) F. Fallouj $(2004,2006)$... The results of all these studies are consistent and demonstrate poor assessment of market needs, the lack of managerial skills including marketing, lack of communication, neglect environmental problems, lack of flexibility in the organization, the growing number financial institutions adopting the strategy imitation which are among the most common causes significant failure of innovations. on the other hand and in contrast to these criteria, competence, experience and high marketing orientation, the market knowledge and evaluation prior interaction with customers .... Count, On the contrary, among the most important factors instrumental in the success of innovations.

\subsection{The Conditions for Success}

The downstream process including driving factors success of banking innovation, does not allow alone of a successful strategic approach Global innovation. Other success factors must be analyzed and taken into account: A.D.Little (1997), PDMA (1993), Edgett, Shiplay \& Forbes (1992), I.P.E.E (1990), C.L. Hoddok (1990), B.A.H 1982), Cooper (1982)... We take the main results which revolve around three area classified by descending order of importance, to namely:

\subsubsection{High Sensitivity and Attention to the Customer}

The customer is considered the main source of new product ideas. This marketing orientation contributes effectively to increase the chances of successful innovations bank.

The primary cause of failure of new banking products and services would it be a fault sensitivity and attention to the client or its real needs? Work Brilman (1997), J. Ph. Deschamps \& Nayak P. Ranganath (1997), Peppers \& M Rogers (1998), AG. Vukonic \& R. Cooper (1991) and the method "Rubbermaid" rather give a positive response and yes to this question.

\subsubsection{A Dynamic Organization that is Account the Specificity of the Banking and Orients towards Innovation}

-It is the quality of the organization and management that determines the success of innovations.

-The support and encouragement of management general are a driving factor for development and success of innovation.

-Innovation is the result of a synergistic inter and functional interface between technicians, salespeople and customers, to be a success.

\subsubsection{Strengthening of Strategic Marketing Bank}

-It is only by strengthening the reflection strategic beginning of the innovation process we can hope to improve its effectiveness. Study Results B.A.H (1982), P.D.M.A (1990), Theys (1994).

-Strengthening Strategic Marketing is profitable for the bank improves very significantly the productivity of its investment in R \& D.

\subsection{The Causes of Failure}

The causes of failure to launch new banking products and services are, therefore, unlike previous conditions for success mentioned. However, among the many Results from studies conducted on this subject, we retain the main causes of failures innovations. They revolve around three axes classified by descending order of importance, to namely:

\subsubsection{Negligence Problems Environment}

-Any banker shall, before developing a strategy innovation, consider the environment. Bank most attentive to its environment will no probably the best equipped to deal with the unexpected and therefore more able to offer products and services that best meet the real needs of the customers.

-A bank that does not know perfectly needs and expectations of the market have little rationale says Quint (1991). So what if it tries to innovate. The environmental analysis social and cultural development of the bank is a condition necessary for successful innovation. 
-Underestimating the competition, its location, speed and the number more banks adopting the strategy Imitation, particularly easy in the field of including banking services due to non protection of innovations through patents is also a major cause of failure new products.

2.2.3 Lack of Pre-Established Process Innovation and Poor Organization of Bank Hamper the Development and Success of Innovation

-Must ensure consistency of process innovation with the strategic objectives and skills, including marketing, bank. Good relations cross-functional services should exist between R \& D and marketing, between marketing and operations, etc...

-A poor general organization of the bank and insurance company or organizational structure ill-suited to innovation or inertia structures and resistance to change.

These are the main results generated from conceptual analysis in this theoretical framework.

The Algerian public banks must organize, innovate and be responsive to their environment that has become very volatile and their demanding clientele. Innovation in general and in that the service in particular acts as a particular challenge for our banks. Face and the transition to the new environment Banking market.

-The Algerian public banks manage it this transformation?

-And by what processes?

-How do managers of public banks Algerian perceive the innovation?

-Are they-depth studies of customer Algerian banking?

And then what are the attitudes and expectations of individual customers to the new banking products and services.

\section{Research Methodology}

As part of the empirical study we conducted among Algerian public banks and their private customers we opted for the completion of two questionnaires. The first is addressed to officials' Algerian public banks and insurance (director's regional) Oran there are 10 selected as follows: BNA, BEA, CPA, BDL, BADR, PSC BANK, CAAR, SAA, CAAT, CRMA.

The National Bank of Algeria (BNA). Credit Populaire d'Algeria (CPA). Popular Credit of Algeria (BEA). The Bank of Agriculture and Rural Development (BADR). The Bank of developments Local (BDL). The National Savings Fund and Provident Bank (CNEP Bank). Algerian Company of Transport Insurance (CAAT). The Algerian Company of Insurance and Reinsur-ance (CAAR). Algerian Insurance Company (SAA). Company of Reinsurance and Mutual Agricultural (CRMA).

And the second individual customers of each bank are a sample of 600 customers.

We used the questionnaire live interview with the manager of each bank that particular customer. We have found this method more adequate and effective in our case, given the size small sample and the possibility of benefiting direct contact with official's banks that customers selected. In fact, we will study the perception of responsible Algerian public banks innovations to bank and the attitude of individual customers to the new Products and Banking (Convergences and differences).

\section{Results}

The majority of Algerian public banks and insurance has not an organizational structure that promotes success of new products and services.

-No bank and insurance conducts studies examined only continuous and thorough behavior bank customers. Almost all managers banks we interviewed, confirm the "lack of information on the market" and the "lack of studies on bank customers Algerian" which are classified in the third position and therefore considered as brakes also important, that can prevent a bank innovate. These barriers should be important overcome, without knowing your market General and specific clientele, banks May take action, including innovation, or certainly neither effectively.

-All Algerian public banks and insurance prove unable to assess the cost. In addition, no bank has a control system and monitoring of new products and the worst most officials interviewed did not even remember the launch date of their new products.

-None of the banks and insurance interviewed establishes a communication strategy of products and services new or existing, according to the precise objectives and the overall marketing strategy of the bank. 
-Almost all Algerian public banks surveyed have a very dense distribution network; the banking network is trained very thin.

\section{For the second questionnaire for the individual customers}

Customer's individuals were chosen in different branches of banks chosen. Given the technical nature of the questionnaire, we were faced with the problem of the control of the subject clients, because we noticed that most of them have absolutely no idea about the new banking products and services, same those initiated by their own bank. This difficulty is not a surprise to us, we expected, but there's a result that is not as obvious. It is for this reason that the customer individuals through the survey we performed with individual customers we reveal this attitude:

The banking innovation is considered by the Customer specific public banks and insurance, as the major factor differentiation and especially the choice of a bank. Individual customers is not satisfied.

Products and services offered by insurance and banks and prefers find other new products and services. According to the findings, the majority of customers, dissatisfaction is the poor reception of customers by staff contacting, the lack of information on products and services available to them, the incompetence of the staff, the execution of banking is very long and the number of branches is very low and the lack of new products.

The direct marketing techniques in general and of mailing in particular are almost nonexistent in the Algerian public banks. The Internet information is a very efficient and less costly, especially for our banks with the evolution and growth of the market information technology and communication in Algeria. That said public banks will have to develop this technique to better inform and educate the customer new banking and insurance products and services.

Although some customers are aware some banking and insurance products and services, they refuses to subscribe because they are either poorly incorrectly informed or received or the paperwork is very slow and complex.

Customer specific pricing judge applied by their insurance and banks and demanded high enough therefore lower fees and rates of interest, especially the quality of service is the qualified poor quality / Price is lacking. In other words, in the minds of customers a high pricing for example, implies the highest quality from the services (reception, after-sales services, speedy, new products and services, diversifying the range of products and services, rapid execution of operations bank information on products and services, the multiplication of agencies, the ease of obtaining credits, sympathy hospitality, friendliness of personal contact). In our field study, these features are absent in Algerian public banks and insurance company.

\section{Conclusion}

More explicitly, our study showed that "the system Algerian bank and insurance has a payment system and based communication methods and outdated technologies, heaviness in the credit assessment procedure, a deficit of management, long delays processing funding applications and decisions funding based more heavily on guarantees on the risk analysis of projects.

In our study, we found a poor quality of basic services accompanied a home misjudged by customer and delays in processing checks and the lack of new product launches and interbank funds transfer considered too long. "Foreign private banks are a threat, they say, if public banks and insurance company they can not be upgraded." The pace Banking Reform in Algeria has not yet reached the desired rate as markets financial underdeveloped, the Quality of service is inefficient and under very important for banking customer's individuals". Financial analysts have revealed that "Analysis of economic data is very favorable to the emergence of a population uses more banks".

Finally, innovation in a particular business in a bank is a diffuse process, collective which involves all functions the company; other hand, this process must be extremely fast to take advantage of advance before being copied by a competitor or contrary to catch up faster compete more innovative. Services companies including the most innovative bank were also brought to develop a culture of innovation and management of human resources and good marketing that motivates and rewards innovation.

Knowing that in the new economy global knowledge of the 21 st century prosperity based on innovation and the knowledge economy, is maximizing their innovative capacity that banks more efficient scale sit down international competitive advantage.

\section{Limits and Prospects of Research Future}

The results of this study have limitations due to the lack of human and material resources and the constraint time. 
For this reason, in the context of our study we wanted our research can be extended to other banks and insurance foreign trade engaged on the market Algeria, identify other results and to make comparative analyzes.

The sample of individual customers Algerian could be expanded, and the provision of more time, material and human resources. A study of the customer "business" sector BtoB could be considered parallel to of individual customers as well as other service sectors such as transport all its branches and the area of telecommunication.

\section{References}

Ansoff, I. (1984). Stratégies du développement de l'entreprise (5th ed.). Hommes \& technique, p. 208.

Badoc, B. (1995). Marketings management pour les sociétés financiers. les éditions d'organisation paris, pp. 55-60.

Bensahel, L. (1997). L introduction à l'économie du service. presses universitaires de Grenoble, P. 38.

Berot, P., \& Piérti, P. (2004). Les entreprises de services innovent aussi. Division services, 982, 28-36.

Bilen, F., \& Sempels, C. (2007). Les fondement du marketing des services: examen critique et evolution. Revue Française du Marketing, 212, 55.

Broustail, J., \& Fery, F. (1993). Le management stratégique de l'innovation. Ed Dalloz, p. 119

Cherchem, M. (2011). L'innovation dans les services comme un pilier d l'économie fondée sur la connaissance (cas des banques publiques et des assurances algériennes. la revue des Sciences de Gestion, 2011(1-2), 33-34.

Crance, P. (2001). Le Marketing de L'innovation des outils pour valoriser la recherche et les technologies nouvelles. Revue Française du marketing, 182, 125.

De Coussergues S. (1996). Gestion da la banque (2nd ed.). Dunod, 1996, P. 21.

Djellal F., \& Galloudj F. (2001). L'organisation du processus d'innovation dans les services : les résultats d'une enquéte postale. Education \& Formation, 59, 9.

Durand, R. (2003). la vraie valeur de l'innovation. L'Expanssion management Review, 71, 29-32.

Eiglier P., \& E. Langeard E. (1994). Servuction (pp. 49-61). Ediscience édition Paris.

Flipo J. P. (1998). Automatisation des Services: de la technologie au marketin. Décisions Marketing, 14, 72-79.

Gadrey J. (1992). l'économie des services. la Découverte, p. 126.

Gallouj C., \& Gallouj F. (1996). L'innovation dans les Service. Edition Economica Paris, pp. 33-39.

Gallouj F. (2007). A model for analysing the innovation dynamic in services: the case of architectural-type services. International Journal of Services Technology and Management.

Gallouj F. (2007). A model for analysing the innovation dynamic in services: the case of architectural-type services. International Journal of Services Technology and Management.

Hélène P., \& Ttremblay T. (2003). l'innovation dans les services. Conseil de la science et de la technologie.

Hermel D. (1992). La franchise de service. Ed Economica, P. 27.

Hodock C. L. (1979). Stratégies behin the winers and losers. The journal of Businee stratégy, Septembre 1979.

Ingham M. (2001). Innovation: de L'exception à la règle. Revue Française de Gestion, 118, 76.

Kotler Ph., \& Dubois. B. (2000). Le marketing Management (10th éd.). Publi Union, P. 115.

Lachmann J. (1993). le Financement des Stratégies de L'innovation. Edition Economica Paris.

Lajili, M. R. (2000). Pour une réussite de l'innovation Bancaire cas du marché Tunisien. Thèse de Doctorat Paris1.

Lovlock C., \& Lapert D. (1999). Marketing des services. Publie union édition Paris, P. 15.

Mc Grath M. E., \& Romeri M. (1994). From experience: R\&D effectiveness. Journal of product innovation Management, 11, 39-42.

Ministère de l'Economie des Finances et de l'Industrie (France). (1998). L'innovation technologique dans les établissement de crédit et les sociétés d'assurance. Retrieved from http://www.insee.fr/sessi/4pages/pdf/4p095.pdf 
Munos A. (1997). Servuction, modes opératoires coopération et technologies. Décision Marketing, 10, 57.

Murphy M. (1999). le boom des services stratégique aux enterprises. Retrieved from http://www.observateurocde.org/news/archivestory.php/aid/101/Le_boom_des_services_strat_E9giques_au x_entreprises.html

OCDE (1999). Forum de la politique de l'entreprise et de l'industrie sur l'économie des services. pp. 26-32.

OCDE (2006). Innovation et productivité dans les services. rapport de l'atelier de Sydney Commission de la Communauté Européenne, P. 57.

Picoeur P. (1993). Services et satisfaction du client. Revue Française de Marketing, 144-145, 47-50.

Richard N. (1991). le Management des services, théorie du moment dans les services (pp. 65-68). Paris: Inter Edition.

STUKERT J. (1989). Implantation et organisation d'un point de vente. Ed de l'assurance France.

Zollinger M. (1989). Monétique et marketing (pp. 86-94). Edition Vuibert.

Zollinger M., \& Lamarque E. (1999). Marketing et stratégies bancaires (p. 21). Edition Dunod Paris. 